Ірина МЕЛЬНИЧУК, orcid.org/0000-0002-5146-9453 кандидат філологічних наук, доиент кафедри української філології

Маріупольського державного університету (Маріуполь, Донечька область, Україна) i.melnychuk@mdu.in.ua

Христина ГУСАК, orcid.org/0000-0003-2053-5435 студентка II курсу кафедри української філологіі Маріупольського державного університету (Маріуполь, Донеиька область, Україна) gusak.kristina15@gmail.com

\title{
ФІЛОСОФІЯ КОХАННЯ В РОМАНІ В. ШЕВЧУКА «ТЕМНА МУЗИКА СОСОН»: ОНТОЛОГІЧНИЙ ВИМІР
}

У статті розглядається онтологічний вимір філософії кохання та його прояв у романі Валерія Шевчука «Темна музика сосон». Досліджено вплив кохання на формування особистості головного героя, здійснено комплексний аналіз проблеми любові та розкрито парадигму моральних иінностей зрілої особистості та ї̈ відображення в романі В. Шевчука.

Наукова новизна статті полягає в спробі иілісного аналізу складного філософського роману «Темна музика сосон» з огляду на екзистенційну проблематику.

У статті зосереджено увагу на екзистениійних концептах роману Валерія Шевчука. Особливу увагу звернено на такі аспекти, як сутність людського існування, самотність, своєрідність жіночого буття, акцентовано основні екзистенційні концепти - смерті, тривоги, відчаю, вибору. Було проаналізовано деякі з перелічених категорій, щчо розкривають сенс буття головного героя твору - чения-самітника Теофіля. Саме його любов постає у творі як деструктивне почуття, в якому більше безнадії, ніж щцастя. У прочесі розгляду роману виявлено, щзо постать головного героя розкривається з двох боків: спочатку - як самітника, а після зустрічі з Терезою людини, ше нарешті почала пізнавати життя з його гріхами та піднесеннями. Герой роману веде внутрішній поєдинок між добром та злом, і врешті, саме ией поєдинок визначає, чи буде він зруйнованим, чи знищить у собі все прекрасне, чи вознесеться над усім земним та буденним. Ці крайнощі вибору можна також охарактеризувати як вияв Еросу $і$ Танатосу. Перший схиляє Теофіля до сприйняття життя як такого, у свою чергу Танатос знаменує відчуження, безглузде проживання, в якому відсутні конфлікти між потребою і задоволенням, між «я» $i$ «ти», між зовнішнім і внутрішнім.

Реальність, котру створює у свої уяві Валерій Шевчук, є значно більиим, аніж художньою моделлю дійсності внутрішньої та зовнішньої. Автор формує літературний світ, котрий синтезує в собі не лише історичну та сучасну тематики, а й ірраціональність простору, котрий торкається і потойбіччя.

Ключові слова: філософія кохання, екзистенціалізм, особистість, Ерос, Танатос. 
Iryna MELNYCHUK, orcid.org/0000-0002-5146-9453 Candidate of Philological Sciences, Associate Professor at the Department of Ukrainian Philology Mariupol State University (Mariupol, Donetsk region, Ukraine) i.melnychuk@mdu.in.ua

\author{
Khrystyna HUSAK, \\ orcid.org/0000-0003-2053-5435 \\ $2^{\text {nd }}$ year Student at the Department of Ukrainian Philology \\ Mariupol State University \\ (Mariupol, Donetsk region, Ukraine) gusak.kristina15@gmail.com
}

\title{
PHILOSOPHY OF LOVE IN V. SHEVCHUK'S NOVEL "DARK MUSIC OF PINE": ONTOLOGICAL DIMENSION
}

The article considers the ontological dimension of the philosophy of love and its manifestation in Valery Shevchuk's novel "Dark Music of Pines". The influence of love on the formation of the protagonist's personality is studied, a complex analysis of the problem of love is carried out and the paradigm of moral values of a mature personality and its reflection in $V$. Shevchuk's novel is revealed.

The scientific novelty of the article is an attempt at a holistic analysis of the complex philosophical novel "The Dark Music of Pines" in view of existential issues.

The article focuses on the existential concepts of Valery Shevchuk's novel. Particular attention is paid to such aspects as the essence of human existence, loneliness, the originality of female existence, emphasizing the basic existential concepts - death, anxiety, despair of choice. Some of these categories were analyzed, revealing the meaning of being the protagonist of the work - a hermit monk Theophilus. It is his love that appears in the work as a destructive feeling in which there is more hopelessness than happiness. In the process of reviewing the novel, it is revealed that the figure of the protagonist is revealed from two sides: first - as a recluse, and after meeting Teresa - a man who finally began to learn about life with its sins and exaltations. The protagonist of the novel leads an internal struggle between good and evil, and in the end, it is this struggle that determines whether it will be destroyed, whether it will destroy everything beautiful in itself, whether it will rise above everything earthly and every day. These extremes of choice can also be described as a manifestation of Eros and Thanatos. The first inclines Theophilus to the perception of life as such, in turn Thanatos marks alienation, meaningless living, in which there are no conflicts between need and pleasure, between "I" and "You", between external and internal.

The reality created by Valery Shevchuk in his imagination is much larger than the artistic model of the reality of the inner and outer. The author forms a literary world that synthesizes not only historical and contemporary themes, but also the irrationality of space, which affects the afterlife.

Key words: philosophy of love, existentialism, personality, Eros, Thanatos.

Постановка проблеми. У літературі минулого століття часто наскрізними темами творів були самотність, людське існування, гріхопадіння, відчуження від усього мирського та песимістичний погляд на життя. На фоні цього всього, звісно ж, посилився інтерес до філософів, які обгрунтовували поведінку людини та вплив іiі внутрішніх демонів та думок.

Творчість Валерія Шевчука увібрала в себе найважливіші тенденції розвитку української літератури кінця XX - початку XXI ст. Не відкидаючи досвіду західноєвропейського мистецтва й українського реалізму $\mathrm{XX}$ століття, письменник від початку виступив як експериментатор, творець нових художніх форм для зображення сучасного йому світу та людини. Свою творчу діяльність автор розпочав ще у 1960-му році, навчаючись на історико-філософському факультеті Київського інституту. Саме тоді він і налаго- див взаємини з літературними студіями та почав глибоко осягати філософію. У своїй творчості Валерій Шевчук глибоко занурюється в історію української літератури, в античну філософію та естетику бароко. Ця тенденція $\epsilon$ визначальною в його романі «Темна музика сосон». Роману передує епіграф з народної казки про «Курочку рябу». Таким сакральним змістом автор відносить свій твір, з одного боку, до народного і щирого модусу, а з іншого боку - до глибинного, адже образ яйця фігурує як у Біблії, так і в язичницьких трактатах. У зв'язку із цим філософія кохання та сенс існування героя, його внутрішня подорож до «джерел власної душі» набувають у романі особливої ваги і становлять інтерес як фактор творення неординарного світу, специфіка якого зумовлена авторським світоглядом.

Аналіз досліджень. Сьогодні існує багато досліджень, присвячених творчості Валерія Шев- 
чука. Твори В. Шевчука завжди були в центрі уваги літературної критики. Особливості його індивідуального стилю досліджували С. Андрусів, Л. Тарнашинська, Г. Сивокінь, В. Фащенко, А. ГорняткоШумилович, Н. Городнюк, М. Жулинський, I. Приліпко, Р. Корогодський, В. Панченко та інші.

Цікавою розвідкою є праця науковця С. Концевича, він називає Шевчука людиною, що творить словом власну своєрідну форму життя, свою правду життя, естетичну та моральну реальність світ, що виростає з особистості творця, з його волі, уяви, філософії (Концевич, 1991: 155).

У свою чергу А. Горнятко-Шумилович у книзі «Проза Валерія Шевчука: традиційне і новаторське» зазначає, що творчість Шевчука - це своєрідний синтез корінного українського та загальноєвропейського мистецько-філософських напрацювань. «Творчі досягнення В. Шевчука можна розглядати саме як результат двох чинників. Один із них уважне ставлення до <..> національних джерел i традицій. Другий же чинник - подолання національної замкненості і сміливе прилучення до прогресивного світового ідейно-художнього досвіду» (Концевич, 1991: 155).

Отже, романи Валерія Шевчука - глибоко філософічні, відзначаються наявністю різноманітних філософських дискурсів (сковородинського, екзистенційного, барокового тощо), фольклорного та міфологічного дискурсу. Письменник вдається до трансформації у своїх творах традиційних міфологічних образів і мотивів у річищі сучасних ідейноестетичних та морально-філософських проблем.

Мета статті - простежити своєрідність утілення філософії кохання в романі В. Шевчука «Темна музика сосон», що формує світоглядноособистісну концепцію у творі.

Виклад основного матеріалу. Неодноразово дослідники зазначали, що екзистенційні категоpiї добра і зла, сенсу буття, самотності, страху, абсурду й ворожості світу наскрізно наявні у творчості Валерія Шевчука. Письменник поставив людину в центр своїх творів. Причому героями стають не відомі особистості, а звичайні, прості люди. «Мої герої - земні, кращі з них хочуть збагнути свій кавальчик світу і прагнуть залишитись у ньому людьми добрими, - ось чому я ними зацікавився. Все ми можемо втрачати, але не добре серце. Все ми можемо руйнувати, але не любов»,пояснює свою творчу філософію Валерій Шевчук.

Так, в екзистенціалізмі феномен любові сприймається в площині «еxistentia», а тому істинна любов сприймається як шлях людини до самої себе, до набуття, осягнення буття свого «Я», яке $\epsilon$ відкритим до буття Іншого, як «Ти».
Якщо звернутися до концепції кохання, то важливо зазначити, що тема любові в європейській філософії бере свій початок у Стародавній Греції. Греки виділяли чотири основних види любові: «ерос» - пристрасна любов, «філія» дружні стосунки, «сторге» - уособлення сімейної та батьківської любові та «агапе» - бути задоволеним. Якраз на основі двох із цих видів і будується концепція кохання в романі Валерія Шевчука, а саме еросу та філії, що визначали процес виникнення якоїсь цілісності через єднання душ і тіл. При цьому в одному випадку йшлося про духовну єдність, а в іншому - про єдність тілесну (Чанышев, 1990: 36).

За сюжетом роману «Темна музика сосон» головний герой твору - Теофіль Білозор, аскет та чернець, що веде відлюдне, відособлене від усього мирського життя. "Через те ц̌ попросив брата - єпископа послати його у Лавришів до давно покинутого ченцями монастирия, де вів би монастирське господарство» (Шевчук, 2003: 18). Доля головного героя роману ченця Теофіля складається 3 двох крайнощів - між «захопленням» життям та «жахом» перед ним, між коханням, бажанням відносин з Терезою та смертю та гріхопадінням. Ці крайнощі вибору можна також охарактеризувати як вияв Еросу і Танатосу. Перший схиляє Теофіля до сприйняття життя як такого, з його радощами, плітками та спокусами, які треба прожити, у свою чергу Танатос знаменує відчуження, безглузде проживання життя заради Бога, де відсутні конфлікти між потребою і задоволенням, між «я» i «ти», між зовнішнім і внутрішнім.

Відрікшись від мирського життя через зради коханої дружини Насті та почавши жити в самоті, Теофіль визначає своє існування як життя, віддалене від спокус і гріхів, його життя сприймається лише як служіння Богу: «Вірив він у те, щзо людина може врятуватися, живучи за своєю волею, але не бажав у цьвому світі кимось бути, йому здавалося, що так і належить чинити доброму християнинові, щчо згодивщись бути ніким, звільниться від проклять життя, а отже, $i$ від гріха, а отже, перебуватиме в Бозі» (Шевчук, 2003: 18).

Але, обравши такий шлях, Теофіль не знаходить омріяного спокою, ніякі молитви та аскеза не допомагають головному герою позбавитись жахіть, дивних снів, що супроводжують його із самого початку твору. Життя в пустелі почало гнітити героя й зовсім не приносило радості. Як визначає автор, «пустеля, в яку втік він від світу, починала переливатись у його душу, і він сам ставав нею» (Шевчук, 2003: 36). 
Герої Валерія Шевчука - неоднозначні на перший погляд. Це і блудниця Тереза, що дарує спасіння, і дідько, котрий проводить до істини, і чернець Теофіль, котрий за праведністю ховає свої страхи та байдужість.

Але все змінилося в один день, коли він зустрів Терезу - повію, яка виявилася його першим коханням, дружиною Настею. Ї̈і гріховний образ розпусної жінки зі скривдженою душею стає протилежністю чесного та чистого Теофіля. На запитання, чому пускає до себе повію, герой зауважує: «Гадав, що коли пожсалію когось нерозважного в світі, такого чи таку, що нещасливіших не знайти, то полюблю його чи ї.. А коли полюблю, гадав, здобуду мир душевний $i$ злагоду. Отож $i$ шукав, а більше сподівався на того чи ту, котрий також прагне подібної злагоди. Бо сказав Соломон, шо любов покриває всі гріхи, а хто шукае любові - провину ховає, хто ж її повторює, оту провину, - розганяє друзів. А ще гадав, щчо немає більшої любові, коли хто покладе душу, як казав святий Іван, бо любов - од Бога» (Шевчук, 2003: 9).

Тереза стає для нього втіленням земного зла і нечистоти, є тим усім, від чого герой намагався себе ізолювати, та разом із тим ця жінка стає рятівницею для ченця, який з появою Терези починає наповнюватися життям. Вона повертає йому здатність відчувати любов, співчуття і страх. Зазначимо, що якщо в східних віруваннях та язичницьких ученнях образ жінки вибудовується довкола світлості, чистоти, багатства, то у християнстві жінка ототожнюється з гріхом.

Окрім того, у творах Валерія Шевчука підіймається питання свободи вибору і вибору свободи. Здавалося б, що це поняття тотожні, проте саме в цьому полягає психоемоційне навантаження кожного його героя. Персонажі Шевчука ведуть внутрішній поєдинок між добрим та лихим, i врешті, саме цей поєдинок визначає, чи в результаті людина буде зруйнована, знищивши в собі все прекрасне, чи вознесеться над усім земним та буденним. І це рішення та цей вибір робить сама людина, спираючись лише на власні моральні орієнтири.

У романі «Темна музика сосон» автор зображує Терезу як таку, що вчинила гріхопадіння. Однак протягом розвитку сюжету Шевчук розкриває, що саме жінка стає провідником до милосердя, любові та піднесення. 3 появою Терези в житті Теофіля починають 3'являтися питання та сумніви. Саме кохання стало тією точкою неповернення, адже головний герой починає переосмислювати поняття добра і зла, святості та гріха, він розуміє, що його відчуження було лише втечею, що характеризує його як слабку людину. Окрім того, залишившись самотнім, Теофіль утратив співчуття до оточуючих, його душа почала черствіти. «Нікому не чинив добра, але й зла, ...плив за хвильми вічної ріки, намагаючись не поставати супроти течії, і мав одну турботу: на тій ріці утриматися» (Шевчук, 2003: 18).

Життя 3 Терезою дає розуміння ченцю, що відмова від почуттів та ілюзія втечі від гріха призводить до інтелектуальної порожнечі й духовної смерті. Автор немов запитує нас: «А це все $\epsilon$ гріхом, що здається гріхом з першого погляду?». Акт Терези, котра входить у дім Теофіля, $\epsilon$ насамперед актом милосердя 3 боку останнього. Як зауважують науковці, саме поняття гріха, як результату милосердя, є парадоксальним. Тобто воно в романі розмиває рамки між тим, що $\epsilon$ добрим, а що $є$ поганим.

Валерій Шевчук відчуває кохання як пізнання істини, бодай на мить, а «сліпоту» до свого ближнього, оманливий погляд на нього - як фатальну ваду людської природи. Двічі доля дає Теофілеві шанс зустріти людину, з якою він може досягнути гармонії, але двічі герой помиляється. Занадто ідеалізуючи чи принижуючи своє кохання, він знаходить у ньому безліч іпостасей, але так і не розуміс його справжньої суті (Топуз, 2008: 378 ).

Характер героїв Валерія Шевчука відповідає описаній філософами-екзистенціалістами концепції існування людини у світі. У творі автора постають проблеми морального вибору, трагічної свободи, абсурду й одноманітності життя, самотності, відчуження та збайдужіння, а також притаманний текстам екзистенціалістів мотив страху перед смертю, печаль, пов'язана 3 нетривалістю та скороминучістю всього, що існує. Дослідники творчості Шевчука підкреслюють, що розроблений ним варіант екзистенціалізму - це філософія оптимістична, яка передбачає існування ладу та гармонії, створює можливість пошуків справжньої мудрості та добра (Берегуляк, 1993: 52).

Висновки. Отже, філософія кохання в романі «Темна музика сосон» полягає в пошуках сенсу життя й вірі в можливість гармонії в цьому світі. Саме завдяки відновленню мирського, сімейного життя 3 його турботами головні герої змогли віднайти внутрішній спокій: «Він ніби відродився, наповнившись тихою радістю, перестала турбувати й жахати темна музика сосон, а з грудей рішуче прогнаного отого скімливого, слинявого звіра, котрого звуть самотністю, який, залізши до людського нутра, помаленьку пожирав його, як дупло дерево...» (Концевич, 1991: 200). 
Цей спокій асоціюється в ченця із сімейним побутом, природністю та духовністю (вірою в Бога та прощення). Таким чином, можна сказати, що головною тезою роману Шевчука $є$ утвердження взаємного кохання, шлюбу й родини, що рівноцінне віднайденню героями власного «Я», шляху до Бога і порятунку душі.
Попри те, що головний герой не знаходить точної відповіді на питання, чи є кохання смертним гріхом, Теофіль дякував Богові не за присвячене спогляданню самотнє життя, а за любов, яку отримав, як неочікуваний дар. Лише в кінці свого шляху він зрозумів, що його життя без любові було безглуздим.

\section{СПИСОК ВИКОРИСТАНИХ ДЖЕРЕЛ}

1. Берегуляк А. Магічний реалізм та літературний міф - зцілення чи панацея у постколоніальному контексті («Дім духів» Ісабель Альєнде та «Дім на горі» Валерія Шевчука). Сучасність. 1993. № 3. С. 67-75.

2. Замбжицька М. Парадокс обернутого sacrum у романі Валерія Шевчука «Темна музика сосон». Питання літературознавства. 2011. № 84. С. 311-316.

3. Концевич Є. В. Таємна зброя Валерія Шевчука. Україна: Наука і культура. Київ, 1991. Вип. 25. С. 379.

4. Тарнашинська Л. Б. Художня галактика Валерія Шевчука: Постать сучасного письменника на тлі західноєвропейської літератури. Київ : Вид-во імені Олени Теліги, 2001. 224 с

5. Топуз А. С. Екзистенційність як художньо-естетичний метод у творчості Валерія Шевчука. Актуальні проблеми слов'янської філології: Міжвузівський збірник наукових статей. Ніжин : ТОВ «Видавицтво «Аспект - Поліграф», 2008. Вип. XVIII: Лінгвістика і літературознавство. С. 378-382.

6. Чанышев А. Н. Любовь в античной Греции. Философия любви. Москва : Политиздат, 1990. С. 36-67.

7. Шевчук В. О. Темна музика сосон. Сад житейський думок, трудів та почуттів. Київ : Акцент, 2003. 448 с.

\section{REFERENCES}

1. Berehulyak A. Mahichnyy realizm ta literaturnyy mif - ztsilennya chy panatseya u postkolonial'nomu konteksti («Dim dukhiv» Isabel' $\mathrm{Al}^{\prime}$ yende ta «Dim na hori» Valeriya Shevchuka). [Magical realism and literary myth - healing or panacea in the postcolonial context ("House of Spirits" by Isabel Allende and "House on the Mountain" by Valery Shevchuk)]. Suchasnist', 1993, Nr 3, pp. $67-75$ [in Ukrainian].

2. Zambzhyts'ka M. Paradoks obernutoho sacrum u roman Valeriya Shevchuka «Temna muzyka soson». [The paradox of the sacrum wrapped in Valery Shevchuk's novel "Dark Music of Pines"]. Questions of literary criticism, 2011, Nr 84, pp. 311-316 [in Ukrainian].

3. Kontsevych Ye. V. Tayemna zbroya Valeriya Shevchuka. Ukrayina: Nauka i kul'tura. [Secret weapon of Valery Shevchuk. Ukraine: Science and Culture]. Kyiv, 1991. Issue 25, 379 p. [in Ukrainian].

4. Tarnashyns'ka L. B. Khudozhnya halaktyka Valeriya Shevchuka: Postat' suchasnoho pys'mennyka na tli zakhidnoyevropeys'koyi literatury [Art galaxy of Valery Shevchuk: The figure of a modern writer against the background of Western European literature]. K. : Vyd-vo imeni Oleny Telihy, 2001, 224 p. [in Ukrainian].

5. Topuz A. S. Ekzystentsiynist' yak khudozhn'o-estetychnyy metod u tvorchosti Valeriya Shevchuka. [Existence as an artistic and aesthetic method in the works of Valery Shevchuk]. Nizhyn. Current issues of Slavic philology: Interuniversity collection of scientific articles. Publishing House "Aspekt - Polihraf", 2008, Issue XVIII: Linguistics and Literary Studies, pp. 378-382 [in Ukrainian].

6. Chanyshev A. N. Lyubov' v antychnoy Hretsyy. Fylosofyya lyubvy. [Love in ancient Greece. Philosophy of love]. M. : Politizdat, 1990, pp. 36-67 [in Russian].

7. Shevchuk V. O. Temna muzyka soson. Sad zhyteys'kyy dumok, trudiv ta pochuttiv. [Dark music of pine trees. The garden of life's thoughts, labors and feelings]. Kyiv, Aktsent, 2003, 448 p. [in Ukrainian]. 